\title{
LOVELOCKOV KONCEPT UDRŽATELNÉHO ÚSTUPU A JEHO KONZEKVENCIE
}

\author{
RICHARD SŤAHEL, Filozofický ústav Slovenskej akadémie vied, Bratislava, SR
}

SŤAHEL, R.: Lovelock's Concept of Sustainable Retreat and its Consequences FILOZOFIA, 74, 2019, No 5, pp. $352-365$

The aim of this study is to identify the key terms and arguments of J. Lovelock's sustainable retreat concept and their analysis with emphasize on the consequences of this concept for political, social and environmental thinking. J. Lovelock points out that considering rapid and complex changes in global environment, marked by the term Anthropocene; we do not have enough time and sources to realize the sustainable development concept. For that reason, it is, according to him, necessary to formulate sustainable retreat concept as a strategy which will allow to prepare for climate change in a way that not only a man as a biological specie, but also civilized society could survive. Even basic theses of this concept indicate a need to revalue majority political concepts, mainly concepts of sovereignty, citizenship, also the freedom of movement and residence, freedom of business and consume, which are fundamentals of neoliberal economic-political system. Retreat expects elaborated and organized migration to beforehand chosen and arranged areas. Opposite to retreat is mass escape chaos that reduces human relations to fight for survival. As J. Lovelock proposed in his sustainable retreat concept, relocating people from areas affected by climate changes to climate oases would mean that rich northern countries give up their current, in fact, isolationistic politics that refuses climate migrants. Therefore the sustainable retreat concept requires much greater competence and mainly willingness to cooperate not only on national, but also on international and global level more than humanity is able to do it currently.

Keywords: Lovelock - Sustainable development - Sustainable retreat - Tribalism Environmental authoritarianism - Anthropocene

\section{Úvod}

James Lovelock je známy najmä ako autor Gaia hypotézy alebo Gaia teórie, teda koncepcie, ktorá chápe ekosystém planéty ako superorganizmus ${ }^{1}$. Gaia teória bola dlho odmietaná a kritizovaná ${ }^{2}$, čo sa však začalo menit’ s rozvojom výskumu klimatických zmien a so vznikom konceptu antropocénu. Niektorí autori dokonca pokladajú najnovšie

\footnotetext{
${ }^{1}$ Lovelock v jednej zo svojich prvých prác Gaiu definuje ,ako zložitú entitu zahŕňajúcu biosféru, atmosféru, oceány a pevninu Zeme, ako celok tvoriaci spätnoväzbový alebo kybernetický systém, ktorý vyhladáva optimálne fyzické a chemické prostredie pre život na tejto planéte“ (Lovelock 1993, 25). ${ }^{2}$ Dôvody a formy kritiky Gaia teórie by stačili na samostatnú štúdiu, preto ich nemožno vyčerpávajúcim spôsobom uviest' na tomto mieste.
} 
poznatky klimatológie a vied o planetárnom systéme za potvrdenie prinajmenšom niektorých téz Gaia teórie. Koncom prvého desat'ročia tohto storočia však Lovelock začal svoju primárne prírodovedeckú koncepciu rozvíjat’aj o sociálno-politické, antropologické, a napokon aj politické a filozofické úvahy. Ich výsledkom je sformulovanie konceptu udržatel'ného ústupu, ktorý Lovelock vytvára ako alternatívu konceptu udržatel'ného rozvoja. Ciel’om tejto štúdie je identifikácia klúǔcových pojmov a argumentov konceptu udržatel'ného ústupu a ich analýza, a to s dôrazom na dôsledky tohto konceptu pre politické, sociálne a environmentálne myslenie.

\section{Antropocén}

Koncept antropocénu je pomerne nový a ešte vždy je predmetom vel'mi rozsiahlej globálnej diskusie. ${ }^{3}$ Lovelockovo chápanie Zeme ako mimoriadne komplexného spätnoväzbového systému, ktorého fyzikálno-chemické charakteristiky ovplyvňuje činnost' bioty, je prinajmenšom anticipáciou niektorých kl'účových premís konceptu antropocénu. Možno ho však považovat' aj za jednu z jeho inšpirácií. ${ }^{4}$ Koncept antropocénu vychádza z toho, že l’udské aktivity významne prispeli k tomu, že relatívne stabilná geologicko-klimatická epocha holocénu, ktorá umožnila vznik pol’nohospodárstva, a tým aj civilizácie, sa preklopila do relatívne nestabilnej, a preto nepredvídatel'nej epochy, označovanej ako antropocén. ${ }^{5}$ Ludstvo sa tak svojou početnost'ou, svojimi technológiami a ich vedl'ajšími, často neželanými dôsledkami, stalo geofyzikálnou silou. Inými slovami, súhrnný vplyv l'udskej činnosti na planétu Zem je taký rozsiahly, že l'udstvo fakticky začalo ovplyvňovat' aj planetárne geologické i klimatické procesy v rozsahu, ktorý geológii umožňuje konštatovat', že holocén sa skončil a začala sa nová, geologickými metódami identifikovatel'ná epocha v dejinách Zeme. ${ }^{6}$

\footnotetext{
${ }^{3} \mathrm{~K}$ pôvodu a vývoju konceptu antropocénu a diskusii, ktorá ho sprevádza, pozri Malhi (2017).

${ }^{4}$ B. Latour dokonca poukazuje na paralely medzi Lovelockovou Gaia teóriou a teóriou G. Bruna či L. Pasteura, a to nielen $v$ ich význame pre kreovanie novej paradigmy či konceptuálneho rámca, ale aj v kritike, odpore a snahách o spochybnenie nielen teórie, ale aj integrity či kompetencie ich autora, ktoré nasledovali po zverejnení ich teórií (Latour 2017, 75 - 110). O Gaia teórii ako o novej vedeckej paradigme hovorí aj D. Bondi, pričom poukazuje na to, že viaceré javy je schopná vysvetlit' jednoduchšie ako darwinizmus, čo je podl'a neho aj jeden z dôvodov, prečo bola Lovelockova teória najintenzívnejšie kritizovaná práve z pozícii neodarwinizmu (Bondi 2015, 130).

5 „Relatívne stabilná, 11700 rokov trvajúca epocha holocénu, je jediný stav planetárneho systému, o ktorom s určitost'ou vieme, že môže podporovat' súčasné l'udské spoločnosti“ (Steffen, W. et al. 2015, 736).

${ }^{6} \mathrm{~K}$ vymedzeniu antropocénu pozri (Steffen, W. et al. 2011a; Steffen, W. et al. 2011b; Steffen, W. et al. 2015; Steffen, W. et al. 2018) a tiež McNeill, Engelke (2014). V týchto, ale aj mnohých d’alších textoch je koncept antropocénu chápaný aj ako paradigmatická zmena, nevyhnutná na uchopenie doteraz vedecky nereflektovaných, mimoriadne komplexných vztahov atmosféry, hydrosféry, litosféry a biosféry na planetárnej úrovni, ktoré sú však zároveň ovplyvňované l’udskými aktivitami, akými sú napr. rôzne formy znečistenia, rozšírené využívanie plastov a betónu, testovanie jadrových zbraní či vel'kochov zdomácnených zvierat. K filozofickej reflexii antropocénu a jeho sociálno-politických dôsledkov pozri Purdy (2015), Angus (2016), Davies (2016), Latour (2017).
} 
V knihe A Rough Ride to the Future (2014) sa Lovelock prihlásil k pojmu antropocénu a často ho používa, pretože - ako píše - „nie je k dispozícii alternatíva, ktorá by bola dostatočne presná“ (Lovelock 2014, 8) na pomenovanie komplexu javov, ktorými l'udstvo ovplyvňuje viaceré planetárne procesy. Na rozdiel od väčšny autorov, ktorí spájajú vznik antropocénu s obdobím medzi rokmi 1750 a $1950^{7}$ však navrhuje datovat' jeho začiatok rokom 1712, pretože v tomto roku vznikol prvý funkčný parný stroj, ktorý na jednej strane spal'oval uhlie, na druhej strane umožnil zintenzívnit' tažbu uhlia. Vznikla tak pomerne lacná a efektívna technológia, ktorá umožňovala čerpanie vody z baní. $Z$ uhlia sa tak stal lacno dostupný zdroj energie, ktorý mohol byt' masovo používaný už nielen na výrobu tepla (kúrenie), ale aj na zefektívnenie všetkých druhov výroby, a neskôr aj dopravy. Bez toho by nemohla vzniknút' globálna konzumná spoločnost'. Technológia parného stroja však zároveň naštartovala prudký rast koncentrácie skleníkových plynov $\mathrm{v}$ atmosfére, ktorý trvá do súčasnosti. Klimatické zmeny spôsobené prudkým nárastom koncentrácie skleníkových plynov v atmosfére teraz ohrozujú nielen prežitie civilizácie ako organizovanej formy spoločenského života, čerpajúcej z akumulácie skúseností a vedomostí stoviek l’udských generácií, ale aj značnej časti zatial' existujúcich rastlinných a živočíšnych druhov, človeka nevynímajúc. ${ }^{8}$ Cenou za lacný zdroj energie, ktorý $\mathrm{v}$ uplynulých tristo rokoch umožnil bezprecedentný nárast l'udskej populácie, ale rovnako aj vzostup kvality a dížky l’udského života, je práve nárast $\mathrm{CO}_{2} \mathrm{v}$ atmosfére (Lovelock 2014, 10). Ide o nepredvídaný a neželaný vedlajší efekt, ktorého dôsledkom je však práve to, že sa z l'udstva stala sila konkurujúca silám, ktoré po miliardy rokov formovali planétu Zem. ${ }^{9}$ Je to však sila, ktorá si aj v dôsledku schopnosti kumulovat poznatky, a tie dokonca aj vedecky spracovávat', prinajmenšom začína uvedomovat' dôsledky svojho konania. ${ }^{10}$ To

\footnotetext{
7 Rok 1750 sa aj v klimatických modeloch označuje ako medzník na určovanie obsahu $\mathrm{CO}_{2}$ $\mathrm{v}$ atmosfére pred začiatkom priemyselnej revolúcie a po ňom, preto ho viacerí autori pokladajú aj za vhodné určenie začiatku antropocénu. Približne v roku 1950 sa začala tzv. vel'ká akcelerácia, teda povojnový technologický rozvoj, spojený s rastom životnej úrovne vel'kej časti l'udskej populácie, a tým aj spotreby všetkých zdrojov. S týmto rokom je však spojený aj nárast používania plastov, agrochémie a betónu, nárast množstva rádionuklidov v atmosfére, vytvorených $\mathrm{v}$ dôsledku pokusných jadrových výbuchov nukleárnych vel'mocí atd'. Pozri Davies (2016), Steffen, W. et al. (2011b) a McNeill, Engelke (2014).

${ }^{8} \mathrm{~V}$ roku 2018 dosiahla koncentrácia $\mathrm{CO}_{2} \mathrm{v}$ atmosfére 410 častíc na milión (ppm), čo je úroveň z obdobia pred 3 - 5 miliónmi rokov, pričom ide o asi dvojnásobnú koncentráciu oproti obdobiu pred 200 rokmi. Z hl'adiska geologických a klimatických procesov nemá takýto prudký nárast obdobu počas celej existencie planéty. Je to príliš prudká zmena na to, aby sa jej vedela prispôsobit’ väčšina existujúcich rastlinných a živočíšnych druhov.

9 „Koncept antropocénu... vznikol aby zachytil... kvantitatívny posun vo vzt’ahu l'udstva a globálneho životného prostredia. Pojem antropocén predpokladá: (i) že Zem v súčasnosti smeruje ku koncu doterajšej geologickej epochy nazývanej holocén a (ii) že za ukončenie holocénu sú do značnej miery zodpovedné l'udské aktivity, teda že l’udstvo sa stalo globálnou geologickou silou“" (Steffen, W. et al. 2011b, 843).

${ }^{10}$ Podl’a Lovelocka možno vynález parného stroja dokonca pokladat’ aj za začiatok procesu „zrýchlenej evolúcie“ (accelerated evolution), ktorá mení planétu mnohonásobne rýchlejšie než Darwinom popísaná biologická evolúcia. Dôsledkom tohto procesu je potom aj exponenciálny nárast luudských poznatkov, ale
} 
podl'a Lovelocka otvára možnost' pripravit' sa na dôsledky klimatických zmien, ktoré sa už nedajú zastavit'. Aby malo l'udstvo šancu prežit' nielen ako živočišny druh, ale zachovat' aj civilizované formy života, musí teda nájst' nové spôsoby organizácie výroby a spotreby, produkcie a distribúcie energie a potravín, ale aj nové spôsoby bývania a nakladania s odpadmi. To všetko v pomerne krátkom čase a pre miliardy ludí.

\section{Udržatel'ný ústup}

Koncept udržatel’ného rozvoja je prakticky jediný z množstva environmentálnych konceptov, ktorý sa dočkal inštitucionalizácie, resp. pokusov o praktické uplatnenie. ${ }^{11}$ Podl'a J. Lovelocka však koncept udržatel'ného rozvoja nie je adekvátnou odpoved’ou na aktuálne hrozby a riziká. Poukazuje na to, že ,udržatel'ný rozvoj jednoducho znamená rast“ (Lovelock 2014, 108). Rast výroby a spotreby znamená väčšiu spotrebu surovín, a tým aj d’alšiu devastáciu životného prostredia, ale aj rast množstva odpadov a skleníkových plynov vypúšt’aných do atmosféry. Snaha o uplatnenie konceptu udržatel'ného rozvoja síce prispieva k udržaniu stability ekonomického systému, ktorý stojí na imperatíve rastu, ale zároveň prehlbuje klimatické zmeny a d’alšie formy devastácie životného prostredia, ako sa to ukazuje na pokračujúcom raste koncentrácie skleníkov plynov v atmosfére. Doslova piše, že na udržatel'ný rozvoj už je neskoro; „my potrebujeme trvalo udržatel'ný ústup“ (Lovelock 2008, 21). ${ }^{12}$ Prinajmenšom rýchlost' klimatických zmien a rozsah vymierania rastlinných a živočiššnych druhov potvrdzuje tézu J. Lovelocka, že na realizáciu konceptu

najmä vynálezov, ktoré odštartovali nielen klimatické zmeny, ale aj „,infláciu civilizácie“ (Lovelock 2014, 65). To však zároveň umožnilo, že l’udstvo sa môže stat' inteligentnou čast'ou samoregulačného systému, ktorý Lovelock označil pojmom Gaia. Túto myšlienku rozvinul Lovelockov žiak T. M. Lenton spolu s B. Latourom do konceptu Gaia 2.0, ktorý predpokladá možnost' využitia súčasných vedeckých a technických poznatkov na to, aby sa l'udstvo stalo aktívnou súčastou samoregulácie kl'účových globálnych biochemických cyklov, napr. v podobe transformácie svetovej ekonomiky na cirkulárnu a plošného využívania technológií obnovitel'ných zdrojov (Lenton, Latour 2018). Sám Lovelock je však k možnostiam technológií obnovitel'ných zdrojov skeptický a zotrváva na svojom stanovisku, podl’a ktorého sa l'udstvo bez jadrovej energie nezaobíde.

${ }^{11}$ Pojem udržatel’nosti definovala správa tzv. Brundtlandovej komisie, ktorá vyšla v roku 1987 pod názvom World Commission on Environment and Development. Our Common Future. Správa poukazuje na súvislost' medzi degradáciou rozličných zložiek životného prostredia a formou a rozsahom spoločenského rozvoja. Koncept udržatel'ného rozvoja potom predpokladá možnost' nájdenia takej formy rozvoja, ktorá nebude devastovat' životné prostredie, a tým aj predpoklady d'alšieho rozvoja. Tento koncept zapracovalo do svojich rozvojových plánov väčšina organizácií OSN a zároveň takmer všetky štáty. Dokonca aj značná čast' ekonomického sektora proklamuje, že jeho aktivity sú realizované s ohl'adom na koncept udržatel'ného rozvoja, aj ked' $\mathrm{v}$ tejto sfére došlo $\mathrm{k}$ redukcii a dezinterpretácii tohto konceptu na „trvalo udržatel’ný rast“. K filozofickým východiskám konceptu udržatel’ného rozvoja pozri Smolková (2018, 736 - 738).

12 Koncept udržatel'ného ústupu prvýkrát formuloval v práci The Revenge of Gaia: Why the Earth Is Fighting Back - and How We Can Still Save Humanity (Lovelock 2006). V českom preklade vyšla o dva roky neskôr (Lovelock 2008). 
udržatel'ného rozvoja v planetárnom rozsahu už nemá l'udstvo dostatok času ${ }^{13}$ a s vel'kou pravdepodobnost'ou ani dostatok zdrojov. ${ }^{14}$

Preto je podl'a Lovelocka potrebné skôr než o rozvoji uvažovat' o ústupe - do miest, ktoré zostanú obývatel'né aj po vzostupe morskej hladiny a rozšírení púští, o spôsobe presídlenia miliónov l'udí z oblastí, ktoré budú zaplavené morom, pohltené púštou, alebo sa stanú neobývatel'nými v dôsledku vysokých teplôt a vlhkosti, o zmene spôsobu života, organizácie spoločnosti, produkcie potravín a energie tak, aby boli vytvorené predpoklady nielen na prežitie l'udstva ako živočíšneho druhu, ale aj na zachovanie civilizácie a jej technických a organizačných poznatkov. Doslova píše: „Musíme nielen prežit', ale zostat' aj civilizovaní a nezdegenerovat' na luzu, v ktorej sa vodcovia gangu pasujú na vojvodcov. Preto teraz musíme prijat' účinné lokálne opatrenia. Predovšetkým musíme zabezpečit' dostatok potravín, odevov, a kým budeme pokračovat' v mestskom živote, tiež energie“ (Lovelock 2012, 75).

Už len základné tézy tohto konceptu však naznačujú potrebu prehodnotenia väčšiny pojmov politického myslenia, najmä však pojmov suverenity, občianstva, vlastníctva, ale aj slobody pohybu a pobytu, slobody podnikat' a konzumovat', teda viacerých l'udských práv ${ }^{15}$, ktoré sú základom neoliberálneho ekonomicko-politického systému. Slovami

${ }^{13}$ S touto tézou súhlasí aj P. Nováček (Nováček 2013).

${ }^{14}$ Globálna spotreba všetkých druhov surovín (obnovitel'ných aj neobnovitel'ných) vzrástla z 22 mld. ton $\mathrm{v}$ roku 1970 na 70 mld. ton v roku 2010 (Shandl et al. 2017). Ak bude súčasné tempo globálneho hospodárskeho rastu pokračovat', v roku 2050 bude globálna spotreba všetkých druhov surovín dosahovat' úroveň 180 mld. ton ročne. Maximalizovaním efektivity využívania dostupných zdrojov a zavedením vysokých uhlíkových daní by globálna spotreba mohla v roku 2050 dosiahnut' úroveň 95 mld. ton. Za ekologicky udržatel'nú úroveň spotreby sa však pokladá okolo 50 mld. ton. Táto hranica však bola prekročená už v roku 2000 (Hickel 2018). Napriek zvyšovaniu efektivity využívania energie a prudkému rozvoju technológií využivajúcich obnovitel'né zdroje sa zatial' nepodarilo dosiahnut decoupling, teda oddelit' hospodársky rast od rastu spotreby zdrojov a rastu produkovaného odpadu a skleníkových plynov. Jedným z dôvodov je tzv. Jevonsov paradox, teda to, že každé zvýšenie efektivity nakoniec vedie k zvýšeniu spotreby - napr. úspornejšie automobilové alebo letecké motory neviedli k zníženiu spotreby ropných produktov, ale k presnému opaku - zlacnenie kilometra cesty alebo letu viedlo $\mathrm{k}$ tomu, že l'udia cestujú viac. Významne k tomu však prispieva celosvetový nárast spotrebných očakávaní ako dôsledok masívnej manipulácie marketingovým a reklamným priemyslom, ale aj pokračujúci rast l'udskej populácie (približne o 80 - 90 miliónov l'udských jedincov ročne), ktorej základné potreby možno uspokojovat' len d’alším rastom priemyselnej výroby a produkcie potravín. Inými slovami, súčasná podoba realizácie konceptu udržatel'ného rozvoja nie je globálne udržatel'ná ani v strednodobom horizonte, nieto ešte trvalo, ako sa pojem sustainability nepresne prekladá do slovenčiny (a češtiny).

Lovelock ako prírodovedec ani v najmenšom nepochybuje o tom, že z konečných zdrojov planéty nie je možný trvalý rast a aj preto označuje udržatel'ný rozvoj za absolútny oxymoron (ultimate oxymoron) a upozorňuje, že politici, resp. vlády by sa mali usilovat' míňat' viac na opatrenia, ktoré umožnia lokálnu adaptáciu na klimatické zmeny a menej na „vizionárske pokusy zachránit’ planétu“ (Lovelock 2014, 93). Tá sa podl’a neho o seba totiž postará aj v prípade, že l’udstvo vyhynie.

${ }^{15}$ „L'udstvo, celkom nepripravené vzhl'adom na humanistické tradície, čelí najvyššej skúške. Zmeny klímy sa zrýchl'ujú, už postupujú a pohodlné životné prostredie, na ktoré sme si zvykli, čoskoro zmietnu. Zmena je normálna súčast' geologickej histórie; jednou z posledných bol prechod Zeme 
J. Lovelocka, najvýznamnejší problém, ktorému l'udstvo čelí, je prežitie. Imperatív rastu preto musí byt' nahradený imperatívom prežitia (Lovelock 2014, 148 - 151). Podl'a Lovelocka však l'udstvo neprežije, ak nepremyslí a nepripraví svoj ústup. To sa však nepodarí, ak bude l'udstvo svojimi intelektuálnymi a čoraz obmedzenejšími materiálnymi zdrojmi plytvat' na plány d’alšieho rozvoja.

Ústup predpokladá premyslený a organizovaný presun do vopred vybraných a pripravených oblastí. Opakom ústupu je chaos masového úteku, ktorý medzil'udské vzt'ahy redukuje na boj o prežitie. Presídlovanie l'udí z klimatickými zmenami ohrozených oblastí do klimatických oáz ${ }^{16}$ by však znamenalo, že krajiny bohatého severu sa vzdajú svojej súčasnej, fakticky izolacionistickej politiky, ktorá odmieta klimatických migrantov. ${ }^{17}$ Koncept udržatel'ného ústupu preto vyžaduje ovel'a vyššiu schopnost' a najmä ochotu spolupracovat', a to nielen na národnej, ale aj na medzinárodnej a globálnej úrovni, než je l'udstvo schopné v súčasnosti.

\section{Hrozba tribalizmu}

Z poznania, že l'udstvo ako celok sa stalo geologickou silou, veličinou schopnou ovplyvňovat' aj planetárnu klímu, však zároveň plynie aj potreba úplne novej filozofickej antropológie. Lovelock sa však nezameriava na vyvracanie tradičných predstáv o človeku, ktorý bojuje proti prírode, či je prírode nadradený, alebo ju určitým spôsobom transcenduje. Nevychádza teda z predstáv, ktoré si o sebe človek vytvára v náboženských či filozofických koncepciách, ale zempirických poznatkov o človeku, ktoré poskytuje biológia. Podl'a Lovelocka je jednou z najzávažnejších hrozieb l'udstva faktická neschopnost' globálnej spolupráce l'udstva. ${ }^{18}$ Tá plynie z toho, že sme „kmeňoví nacionalisti“", a to podl’a neho už na genetickej úrovni. ${ }^{19}$ Doslova tvrdí, že tribalizmus je „tak pevnou súčast'ou našej prirodzenosti, že je malá šanca zmenit' ho vzdelávaním,

z dlhej doby l’adovej do súčasného mierneho interglaciálu. Na blížiacej sa kríze je nezvyklé to, že jej pôvodcami sme my l'udia a nič také závažné sa na Zemi nedialo od dlhého horúceho obdobia na začiatku eocénu pred pät'desiatimi piatimi miliónmi rokov, ked' boli zmeny väčšie než tie medzi dobou l'adovou a 19. storočím a trvali 200000 rokov“ (Lovelock 2008, 21).

16 „Tí, čo prežijú prebiehajúcu krízu, nájdu nový domov v oázach a na miestach zatial’ dostatočne chladných a vlhkých na život. Môže trvat' stovky tisíc rokov, než bude Gaia znovu tou istou sviežou planétou, akú sme kedysi poznali“ (Lovelock 2012, 176).

${ }^{17}$ Otvára sa tým otázka práva na presídlenie, bez ktorého sa pre rastúci počet l’udí, či dokonca celých národov, stáva nedostupné už základné l’udské právo - právo na život. Ku konceptu práva na presídlenie pozri Risse (2009).

18 „Najväčšou hrozbou nie sú samotné klimatické zmeny, ale sprostredkovane hladomor, súperenie o priestor a zdroje či vojny“ (Lovelock 2012,33). Lovelock je skeptický vzhl'adom na možnosti zastavit', či dokonca zvrátit' klimatické zmeny. Opakovane tvrdí, že l'udstvo sa na ne musí pripravit', resp. adaptovat'. To sa však nepodarí, kým budeme uvažovat' v klasických kategóriách rozvoja, vlastníctva, suverenity či národných záujmov.

19 Biologickú podstatu skupinového myslenia podporuje viacero súčasných výskumov v oblasti antropológie i biológie. Pozri napr. Sapolsky (2019). 
selektívnym plodením alebo genetickými manipuláciami. Či sa nám to páči alebo nie, ak sme konfrontovaní s hrozbou invázie na naše územie, budeme odpovedat' kmeňovo. Na druhej strane, ak sme konfrontovaní s vel'kou prírodnou katastrofou, idea, že sme súčast'ou l'udstva ako by to bol náš kmeň, v nás evokuje len minimálnu reakciu, pokial' katastrofou nie sme zasiahnutí priamo“ (Lovelock 2014, 147). Koncept l’udstva, ktoré vie ako celok reagovat' na súčasné globálne výzvy a ohrozenia, podla neho „znie dobre v politických prejavoch a prednáškach, ale je v zásade mimo chápania väčšiny z nás“ (Lovelock 2014, 148). V tejto súvislosti preto kladie znepokojivú otázku: „Čo ak je v skutočnosti kmeň alebo národ najväčší možný celok (organizácie ludskej spoločnosti)?“ (Lovelock 2014, 152) Izolacionistické reakcie mnohých štátov na súčasné globálne hrozby, vrátane tých klimatických, a bujnejúci separatizmus alebo fragmentácia komplexných moderných spoločností na navzájom nekomunikujúce skupinky prívržencov politických strán, vodcov, alebo aj športových klubov, či tribalizácia, ku ktorej dochádza v tzv. skrachovaných štátoch, prinajmenšom poukazujú na naliehavost' tejto otázky. ${ }^{20}$ Osobitne ak sa jednoznačne ukazuje, že podmienkou zmiernenia dôsledkov klimatických zmien a d’alších prejavov devastácie životného prostredia, a tým aj prežitia l'udstva, je práve schopnost' a ochota ludstva spolupracovat'. Práve o tej však Lovelock pochybuje, rovnako ako o možnosti zmeny ludskej povahy, spôsobu myslenia a reakcií na ohrozenie. Doslova píše: „Najviac zo všetkého potrebujeme zmenit' našu povahu a spôsob myslenia, ako ich menia kmeňové národy, ked' tušia skutočné nebezpečenstvo“ (Lovelock 2008, 29). Reakcia viacerých štátov na dôsledky klimatických zmien (čoraz silnejšie a častejšie hurikány a veterné smršte, rozsiahle lesné požiare, záplavy, zosuny pôdy, rozširovanie púští, zvyšovanie hladiny morí a oceánov) však naznačujú, že k žiadnej takejto zmene nedochádza.

Lovelock však nie je prvý environmentálny myslitel', ktorý tento problém identifikoval. Poukázal naň A. Gore, ktorý sa už začiatkom devät'desiatych rokov minulého storočia zamýšlal nad možnostami politickej priechodnosti potrebných zmien v organizácii a prioritách globálnej civilizácie. Okrem nedostatku času Gore videl d’alší moment, ktorý globálnu krízu životného prostredia ešte väčšmi prehlbuje, práve v neschopnosti spolupracovat'. Jedinečnost' tejto krízy je totiž okrem iného v tom, že je to kríza skutočne globálna, síce rozličnou mierou a v konkrétnych regiónoch odlišným spôsobom, ale aj tak sa týka celého l'udstva. Gore preto zdôrazňuje, že potrebné zmeny si vyžadujú globálny plán a globálnu koordináciu jeho realizácie, teda doslova spoluprácu celého

\footnotetext{
${ }^{20}$ Kmeňovo, teda iracionálne sa podl’a Lovelocka správajú aj členovia vedeckej obce, ked' bojujú za svoj odbor, vedeckú školu či pracovisko, ale tiež v časoch vojny, ked’ celý svoj intelektuálny potenciál dávajú k dispozícii svojej krajine, aby jej pomohli porazit' nepriatel'a, nie aby pozdvihli l'udstvo (Lovelock 2014, 24 -28). Veda sa pritom pokladá za racionálnu činnost', ktorú emócie a iné l’udské slabosti ovplyvňujú nanajvýš okrajovo. Podl'a Lovelocka však „l'udia nevyhnutne, v dôsledku svojho evolučného dedičstva, spontánne konajú kolektívne ako gangy, loby, učené spoločnosti, politické strany a kamarátske party“ (Lovelock 2014, 103), a to napriek tomu, že takéto konanie je často iracionálne.
} 
ludstva. Ludstvo však ako celok nikdy nespolupracovalo „v globálnom meradle na žiadnom probléme, ktorý by sa stupňom obtiažnosti blížil tomu súčasnému“ (Gore 2000, 262). Lovelock teda podobne ako Gore poukazuje na to, že vieme mobilizovat' ludí aj zdroje, či dokonca obetovat' sa v boji proti ideologickým, náboženským alebo etnickým nepriatel'om, ale podobného nasadenia za zachovanie environmentálnych predpokladov existencie civilizácie či l’udstva zrejme v masovom meradle nie sme schopní okrem iného aj preto, že l'udstvo doteraz nečelilo takejto hrozbe, a preto nemá $\mathrm{k}$ dispozícii praktické skúsenosti ani vzory takejto spolupráce, ktoré by boli hodné nasledovania.

Lovelock však z toho vyvodzuje iné závery ako Gore, ktorého pozícia sa bliži k tomu, čo sa tradične označuje za kozmopolitizmus. ${ }^{21}$ Vzhl'adom na jeho pochybnost' o schopnosti spolupracovat' v rámci celku väčšieho ako kmeň alebo národ je jasné, že akúkol'vek verziu kozmopolitizmu pokladá za utopizmus. ${ }^{22}$ Je to zjavné aj z toho, ako opakovane zdôrazňuje potrebu vytvorenia pravidiel pre klimatické oázy, ktorými podl’a neho budú relatívne malé, ale zato husto obývané mestá, ktoré prirovnáva $\mathrm{k}$ superorganizmom, úl'om alebo termitiskám. Z kontextu jeho úvah vyplýva, že v dôsledku radikálnej zmeny klímy očakáva skôr kolaps existujúceho systému medzinárodných politických i obchodných vzt’ahov ako prehíbenie medzinárodnej spolupráce, či dokonca integrácie. ${ }^{23}$ Pokusy zachránit’ sa v rámci svojho kmeňa, komunity či etnika bez ohl’adu na ostatných, či dokonca na ich úkor, sú pravdepodobnejšie ako „kozmopolitný moment“" ktorý v takejto situácii očakáva U. Beck (Beck 2015, 80). Úsilie viacerých štátov vyviaznut’ z existujúcich zmluvných záväzkov vypovedaním už existujúcich zmlúv alebo odmietaním tých nových ${ }^{24}$ ukazuje, že renacionalizácia, ako tento trend pomenoval (a zároveň pred ním varoval) U. Beck ${ }^{25}$, je k realite bližšie ako väčšina kozmopolitných teórií či integračných či globalizačných ${ }^{26}$ procesov.

\section{Environmentálny autoritarianizmus}

Lovelock vidí budúcnost' l'udstva v mestách, ktoré by boli špeciálne vybudované na to, aby umožnili prežitie aspoň časti súčasnej populácie v novom klimatickom režime. Na ich

\footnotetext{
${ }^{21} \mathrm{~K}$ diskusii o súčasných podobách kozmopolitizmu pozri Bureš (2019) a tiež Lysoňková (2015).

22 Do tejto kategórie by pravdepodobne zaradil aj úvahy o transformácii súčasnej spoločnosti na planetárnu civilizáciu (Raskin 2016), ekologickú civilizáciu, ktorá by nahradila súčasnú industriálnu civilizáciu (Jiahua 2014) alebo úvahy o možnosti rozšírenia inštitútu spoločenskej zmluvy z národnej na nadnárodnú úroveň (St’ahel 2018).

23 „Hned’ ako sa Zem začne posúvat' do nového horúceho štádia, zmena klímy určite naruší politický a obchodný svet“" (Lovelock 2008, 28).

${ }^{24}$ Napr. úsilie Vel'kej Británie zbavit’ sa väčšiny svojich l’udskoprávnych záväzkov vystúpením z EÚ, vypovedanie Parížskej klimatickej dohody zo strany USA alebo odmietnutie pripravovaného migračného paktu Slovenskou republikou, ale aj viacerými d’alšími krajinami.

${ }^{25} \mathrm{~K}$ tomu pozri Stahel (2017).

${ }^{26}$ Azda okrem „globálneho útlaku, ktorého rozsah, intenzita, mocenské poistky, nezákonnost' a všestranná politická podpora nemajú historickú analógiu“, rovnako ako nemajú historickú analógiu „zisky, ktoré spoločnost' globálneho útlaku prináša, ani miera koncentrácie bohatstva u tak početne obmedzenej skupiny l'udí, ktorí dnes vládnu svetu tým, že ho vlastnia“" (Horyna 2017, 137).
} 
vybudovanie bude potrebné využit tie najnovšie technológie a poznatky všetkých vied už len preto, že väčšina súčasnej energetickej, dopravnej i obytnej infraštruktúry nie je schopná znášat teplotné extrémy či také rýchlosti vetra, aké už dnes prinášajú klimatické zmeny. Mnohé, neraz aj mnohomiliónové metropoly sú vybudované na miestach, ktoré v dôsledku klimatických zmien pohltí more alebo púšt', prípadne sú v regiónoch, kde nárast priemernej teploty a vlhkosti vytvorí klimatické pomery nezlučitel'né s l'udským životom. Lovelock však zároveň zdôrazňuje, že: „Budeme potrebovat' súbor pravidiel pre klimatické oázy“" (Lovelock 2012, 185). Existujúce koncepty usporiadania spoločnosti vznikli v celkom inom klimatickom režime, než v akom bude v blízkej budúcnosti žit' už súčasná generácia, takže mnohé zo súčasných hrozieb nevedia ani pomenovat', a preto nie sú schopné ani vytvorit', tobôž nie zdôvodnit' systém práv a povinností, ktorý by určoval rámec medzil'udským a spoločenským vzt'ahom v komunitách, kde možno ani dýchatel'ný vzduch nebude takou samozrejmostou, za akú ho máme v súčasnosti. Lovelock je však skeptický v otázke možnosti prijat' potrebné pravidlá demokraticky. Dokonca tvrdí, že: „Možno budeme musiet' prijat' určité obmedzenia, prídelový systém ${ }^{27}$ a brannú povinnost' ako v obdobiach vojny, a navyše sa ešte na nejaký čas vzdat' slobody“ (Lovelock 2008, 179). Už len reakcie na pokusy o zavádzanie uhlíkovej dane ukazujú, že prijatie potrebných pravidiel demokratickou procedúrou na národnej, nieto ešte na globálnej úrovni, je nepravdepodobné. Strana, ktorá by voličom sl'ubovala obmedzenie slobody konzumu či neobmedzeného hromadenia majetku, nemá šancu získat' masívnu podporu voličov. Ovel’a pravdepodobnejší je postoj, ktorý J. Habermas označil ako „šovinizmus blahobytu“ (Habermas 2004, 199). Ten sa prejavuje práve neochotou krajín bohatého severu prijímat' environmentálnych utečencov z oblastí, ktoré sú preukázatel’ne zaplavované morom alebo neobývatel'né v dôsledku rozširovania púští. Nielen na Slovensku, ale vo väčšine krajín globálneho Severu nemá potreba obmedzovat' spotrebu, a tým aj životnú úroveň, masovú podporu, hoci je čoraz zjavnejšie, že značná čast' kvality života sa v rozvinutých krajinách dosahuje na úkor kvality životného prostredia, zdravia, dostupnosti vody a potravy značnej časti obyvatel'stva krajín chudobného globálneho Juhu. Zvyšovanie životnej úrovne, rast HDP, teda výroby a spotreby sú stále kritériom úspešnosti vlády.

\footnotetext{
${ }^{27}$ Ked' koncom októbra 2012 zasiahla východ USA a Kanady superbúrka Sandy, spôsobila smrt' niekol'kých desiatok l'udí, záplavy na rozsiahlych územiach a d'alšie škody presahujúce hodnotu 50 miliárd dolárov, $\mathrm{v}$ dôsledku ktorých skolaboval systém zásobovania, takže napr. v New Yorku bol dočasne zavedený prídelový systém na pohonné hmoty a niektoré d’alšie komodity. V roku 2017, ked' hurikánová sezóna dosiahla nové rekordy čo do rozsahu búrok, ich počtu, frekvencie, materiálnych škôd i l'udských obetí sa už v juhovýchodnej Ázii, Karibiku i na juhu USA vyhlasovanie výnimočného stavu a zavádzanie prídelového systému v postihnutých oblastiach stalo bežnou rutinou. A to aj v oblastiach postihnutých rozsiahlymi lesnými požiarmi či suchom, ktoré si napr. v Kapskom meste, ale aj v mnohých iných lokalitách po celom svete vynútilo zavedenie prídelového systém na vodu. Ukázalo sa tak, že Lovelockova vízia je ovel’a reálnejšia, než by sa mohlo zdat' len pred pár rokmi.
} 
Vzhl'adom na vyššie zmienenú antropológiu je preto pochopitel'né aj to, že Lovelock odmieta egalitarianizmus (Lovelock 2014, 144 - 145) ako východiskový koncept, o ktorý by sa mohli opriet' pravidlá spoločenskej organizácie mestských superorganizmov budúcnosti. Lovelock však ako egalitarianizmus označuje to, čo by sme mohli nazvat' demokratickou alebo občianskou rovnostou, teda to, čo sa dnes v právnych a politických systémoch krajín globálneho Severu aspoň v teoretickej rovine pokladá za základný princíp. Ich suspendovanie je prípustné iba v čase výnimočného stavu alebo vojny a vo všeobecnosti sa predpokladá, že k tomu môže dôjst' iba na obmedzený čas. Lovelock však opakovane zdôrazňuje, že obdobie, počas ktorého bude l'udstvo čelit' nedostatku potravy, vody a klimatickým pomerom umožňujúcim život l'udských komunít, môže trvat' aj podstatne dlhšie ako niekol'ko storočí či tisícročí. $\mathrm{V}$ jeho ponímaní by teda suspendovanie súčasného občianskeho statusu nebolo dočasné, ale trvalé. To by zo všetkých súčasných štátnych ústav i medzinárodných l'udskoprávnych dohôd urobilo historické kuriozity.

Lovelock si je toho zjavne vedomý, pričom zdôrazňuje, že situácia, do ktorej sa l'udstvo v dôsledku klimatických zmien dostáva, je závažnejšia a ohrozuje ovel'a viac l’udí, než mala druhá svetová vojna obetí. Pritom však zdôrazñuje, že ide o hrozbu, ktorá je zvládnutel'ná, vyžaduje si však inú organizáciu spoločnosti, postavenú na iných imperatívoch, princípoch a koncepciách, než pokladáme za samozrejmé, alebo aspoň akceptovatel'né v súčasnosti. Ako príklad uvádza Singapur, teda mnohomiliónové mesto, ktoré leží v oblasti s klímou, akej bude v blízkej budúcnosti čelit' značná čast' l'udskej populácie. Napriek tomu je to mesto s vysokou životnou úrovňou i celkovým indexom rozvoja. „Singapur je napriek teplu a vlhkosti jedno z najžiadanejších miest na život. ... Singapur však bol diktátorský, nie demokratický... počas druhej svetovej vojny bola ale demokracia suspendovaná vo viacerých, predtým demokratických, štátoch. Možno bude potrebné podobné suspendovanie demokracie, ked' sa klimatické a iné zmeny stanú natol'ko závažné a smrtiace ako vel'ká vojna“(Lovelock 2014, 119 - 120).

Stratégiu, ktorú Lovelock navrhuje v rámci svojho konceptu udržatel'ného ústupu, možno popísat' aj slovami M. Beesona ako environmentálny autoritarianizmus (Beeson 2010), ktorý upozornil na to, že pokračujúca degradácia životného prostredia bude čoraz viac ohrozovat' stabilitu existujúcich politických režimov. V kombinácii s nedostatkom potravy a vody ako dôsledkom klimatických zmien bude podla Beesona čoraz viac režimov siahat' $\mathrm{k}$ autoriatarianizmu, len aby udržali aspoň určitú mieru verejného poriadku. V reakcii na túto esej neskôr B. Gilley poukázal na to, že politika, ktorú uplatňuje Čína v úsilí zmiernit následky klimatických zmien a pripravit' sa na očakávané, ovel’a závažnejšie environmentálne i sociálne dôsledky pokračujúcej zmeny klímy, nesie všetky znaky toho, čo Beeson označil ako environmentálny autoritarianizmus (Gilley 2012). Č́́na sa navyše usiluje usmerňovat' urbanizačné procesy cielavedomým budovaním miest, ktoré sú 
projektované so zretel'om na klimatické zmeny. ${ }^{28}$ Vzhl'adom na rastúci vplyv Č́́ny vo svete, ale aj na to, že čínsky model rozvoja sa stáva vzorom pre množstvo rozvojových krajín, je možné, že podobných príkladov bude pribúdat'. Už len to bude krajiny globálneho Severu nútit', aby nanovo premysleli koncepty a imperatívy, na ktorých sú postavené ich vlastné princípy organizácie spoločnosti a medzil’udských vzt’ahov.

\section{Záver}

Lovelockov koncept udržatel'ného ústupu možno pokladat' za jeden z viacerých pokusov domysliet' sociálne a politické dôsledky antropocénu. Lovelock však ide ešte d’alej, ked' sa pokúša načrtnút' rámec, v rámci ktorého sa podl'a neho budú vytvárat' nové pravidlá organizácie l'udskej spoločnosti a medzil'udských vzt'ahov. Podla neho budú musiet' zohl'adňovat' úplne novú, pre väčšinu súčasnej populácie stále nepredstavitelnú situáciu nedostatku zdrojov, a to aj tých základných ako voda a potraviny, a v neposlednom rade stav planéty, ked' budú mnohé dnes husto obývané oblasti neobývatel’né. Migračné pohyby a zápasy o udržanie územia, resp. získanie prístupu $\mathrm{k}$ nemu prekreslia nielen politicko-ekonomickú mapu sveta, ale radikálne zmenia aj spôsob života tých komunít, ktorých sa klimatické zmeny nedotknú natol'ko, aby museli lokalitu svojho umiestnenia opustit'. Lovelockove úvahy tak možno chápat' ako filozofiu globálneho klimatického alebo environmentálneho kolapsu, ako filozofiu aj ked' nie trvalého, ale rozhodne dlhodobého výnimočného stavu, ked' bude množstvo súčasných samozrejmostí nedostupných. Vzhl’adom na to, že globálne iniciatívy na zmiernenie devastácie životného prostredia a klimatických zmien zlyhávajú, alebo sú privel'mi pomalé na to, aby stihli transformovat' súčasnú globálnu fosílnu ekonomiku na ekonomiku uhlíkovo neutrálnu, formuluje Lovelock svoj koncept ako filozofiu prežitia malých klimatických oáz, v ktorých budú všetky l'udské aktivity podriadené imperatívu prežitia. Čím dlhšie sa budú súčasné spoločnosti vzpierat' radikálnym zmenám v organizácii výroby a spotreby, v nakladaní so zdrojmi a odpadmi, tým pravdepodobnejšie sa budúce spôsoby organizácie spoločnosti budú blížit' k tomu, čo predikuje J. Lovelock.

\footnotetext{
${ }^{28}$ Rýchlost' urbanizácie v Č́ne nemá v l'udských dejinách obdobu. V roku 1978 bola miera urbanizácie Č́ny 19,72\%, v roku 2015 už 56,1 \%, v roku 2016 vzrástla na 57,35\%. Mestská populácia vzrástla z 170 mil. na 770 mil. l'udí, pričom počet miest vzrástol zo 193 na 656, pričom sa budujú d’alšie. V roku 1981 zaberala mestská zástavba $7000 \mathrm{~km}^{2}$, v roku 2015 už 49000 km² Č́ny. Medzi rokmi 2010 a 2015 vzrástla mestská populácia o 101,37 mil. Do roku 2030 má urbanizácia Číny dosiahnut’ 70 \%. V mestách pritom už v súčasnosti vzniká až $80 \%$ čínskej hospodárskej produkcie. Tieto procesy umožnili aj prudké zvýšenie kvality života, napr. napojenia na verejné vodovody, kanalizáciu či elektrickú rozvodnú siet', a tým paradoxne aj kvality životného prostredia. Zvýšila sa aj dostupnost' vzdelania a zdravotnej starostlivosti, atd'. K tomu pozri Chen, Lees (2018) a Zhenhua, Jiahua (2018). Tieto procesy okrem iného znamenajú, že tradične rurálna a agrárna kultúra Číny sa za niekol'ko desat'ročí zmenila na urbánnu a priemyselnú. To vyvolalo aj potrebu formulovat úplne nové pravidlá upravujúce medzil’udské a spoločenské vzt'ahy. Ich forma a obsah sú ovel'a bližšie tomu, o čom hovorí Lovelock, než euroamerickým predstavám.
} 
Lovelock bol doteraz kritizovaný zväčša za Gaia teóriu, resp. za niektoré jej tézy, pričom jeho koncept udržatel'ného ústupu ostáva akoby nepovšimnutý. Ide však o koncept, ktorý otvára celú sériu otázok $\mathrm{k}$ filozofii spoločnosti, práva, štátu a špecificky l'udských práv. Základné tézy toho konceptu sú totiž v rozpore tak s konceptom udržatel'ného rozvoja (ako novej, resp. environmentalizovanej verzie prakticky osvietenského konceptu pokroku), ako aj s konceptom štátnej suverenity či l'udských práv. Možno súhlasit's tým, že koncept udržatel'ného rozvoja je prekonaný, koncept udržatel'ného ústupu je však nerealizovatel'ný v súčasnom paradigmatickom rámci. Nevyhnutnost' jeho zmeny je zjavná, rovnako ako to, že pravdepodobnost' tejto zmeny ako výsledku demokratických procesov je minimálna. Koncept udržatel’ného rozvoja dával aspoň teoretickú nádej na zlepšenie života nemajetnej väčšiny svetovej populácie, čím pomáhal udržat' sociálny zmier. Koncept udržatel'ného ústupu však otvorene poukazuje na to, že niečo také je v dôsledku obmedzených zdrojov a klimatických zmien utópiou. Možné sociálno-politické dôsledky vo svete polarizovanom extrémnou príjmovou a majetkovou nerovnost'ou budú možnost' akceptácie konceptu udržatel'ného ústupu obmedzovat' možno ešte väčšmi ako formálne demokratické procedúry alebo súčasné formy tribalizmu či nacionalizmu, na ktoré poukazuje Lovelock.

\section{Literatúra}

ANGUS, I. (2016): Facing the Anthropocene: Fossil capitalism and the crisis of the earth system. New York: Monthly Review Press.

BEESON, M. (2010): The comming of environmental autoritarianism. Environmental Politics, 21 (2), $287-307$.

BECK, U. (2015): Emancipatory catastrophism: What does it mean to climate change and risk society? Current Sociology, 63 (1) $75-88$.

BONDI, D. (2015): Gaia and the Anthropocene; or, The Return of Teleology. Telos (Political Critiques of the Anthropocene), 172, 125 - 137.

BUREŠ, O. (2019): Budoucnost lidstva za soumraku éry národních států: předpoklady a vyhlídky kosmopolitní konstelace. Filozofia, 74 (2), 81 - 94. DOI: https://doi.org/10.31577/filozofia.2019.74.2.1.

DAVIES, J. (2016): The Birth Of The Anthropocene. Oakland: University of California Press.

GILLEY, B. (2012): Autoritarian environmentalism and China's response to climate change. Environmental Politics, 19 (2), 276 - 294.

GORE, A. (2000): Země na misce vah. Ekologie a lidský duch. Přel. J. Jařab. Praha: ARGO.

HABERMAS, J. (2004): Státní občanstí a národní identita (1990). Filosofický časopis, 52 (2), 185 205.

HICKEL, J. (2018): Why Growth Can't Be Green. Fereign Policy. September 12, 2018. Dostupné na: https://foreignpolicy.com/2018/09/12/why-growth-cant-be-green/ (Navštívené: 15. 12. 2018)

HORYNA, B. (2017): Globalizace rozdílů. In: Suša, O., Hrubec, M. a kol.: Riziková společnost a globálni ohrožení. Ke kritické teorii Ulricha Becka. Praha: SLON, 131 - 162. 
CHEN, G. C., LEES, CH. (2018): The New, Green, Urbanization in China: Between Authoritarian Environmentalism and Decentralization. Chinese Political Science Review, 3 (2), 212 - 231. DOI: https://oi.org/10.1007/ s41111-018-0095-1.

JIAHUA, P. (2014): China's Environmental Governing and Ecological Civilization. Beijing: China Social Science Press and Springer-Verlag GmbH.

LATOUR, B. (2017): Facing Gaia. Eight Lectures on the New Climate Regime. Cambridge: Polity Press.

LENTON, T. M., LATOUR, B. (2018): Gaia 2.0. ScienceI, 361 (6407), 1066 - 1068. DOI: 10.1126/science.aau0427.

LOVELOCK, J. (1993): Gaia. Nový pohled na život na Zemi. Přel. J. Edlman. Tulčík: Abies.

LOVELOCK, J. (1994): Gaia. Živoucí planeta. Přel. A. Markoš. Praha: Mladá fronta.

LOVELOCK, J. (2006): The Revenge of Gaia: Why the Earth Is Fighting Back - and How We Can Still Save Humanity. Santa Barbara (California): Allen Lane.

LOVELOCK, J. (2008): Gaia vrací úder. Proč se Země bráni a jak ještě můžeme zachránit lidstvo. Přel. J. Havlíčková. Praha: Academia.

LOVELOCK, J. (2012): Mizející tvár Gaii. Poslední varování. Přel. P. Královcová. Praha: Academia.

LOVELOCK, J. (2014): A Rough Ride to the Future. New York: The Overlook Press.

LYSOŇKOVÁ, M. (2015): Pluralitní svět států a vize globální jednoty. Ke Kantově a Habermasově verzi kozmopolitizmu. Filozofia, 70 (2), 81 - 93.

MALHI, Y. (2017): The Concept of the Anthropocene. Annual Review of Environment and Resources. 42, 77 - 104. DOI: https://doi.org/10.1146/annurev-environ-102016-060854.

MCNEILL, J. R., ENGELKE, P. (2014): The Great Acceleration : an environmental history of the anthropocene since 1945. Cambridge: The Belkap Press of Harvard University Press.

NOVÁČEK, P. (2013): After Rio+20: Preparing for Sustainable Retreat? Quaestiones Geographicae 32 (1), 55 - 60. DOI: https://doi.org/10.2478/quageo-2013-0007.

PURDY, J. (2015): After Nature: a politics for the anthropocene. Cambridge: Harvard University Press.

RASKIN, P. (2016): Jorney to Earthland. The Great Transition to Planetary Civilization. Boston: Tellus Institute.

RISSE, M. (2009): The Right to Relocation: Disappearing Island Nations and Common Ownership of the Earth. Ethics \& International Affairs, 23 (3), 281 - 300. DOI: https://doi.org/10.1111/j.1747-7093.2009.00218.x

SAPOLSKY, L. (2019): This Is Your Brain on Nationalism. The Biology of Us and Them. Forein Affairs [online], 98 (2). Dostupné na: https://www.foreignaffairs.com/articles/2019-02-12/yourbrain-nationalism (Navštívené 18. 3. 2019).

SCHANDL, H., FISHER-KOWALSKI, M., WEST, J., GILJUM, S. (2018): Global Material Flows and Resource Productivity: Forty Years of Evidence. Journal of Industrial Ecology, 22 (4), 827 - 838. DOI: https://onlinelibrary.wiley.com/doi/10.1111/anu.12626.

STEFFEN, W. et al. (2011a): The Anthropocene: From Global Change to Planetary Stewardship. AMBIO November 2011, 40 (7), 739 - 761.

STEFFEN, W. et al. (2011b): The Anthropocene: Conceptual and historical perspectives. Philosophical Transactions of The Royal Society A: Mathematical Physical and Engineering Sciences, 369(1938), 842-867. DOI: 10.1098/rsta.2010.0327.

STEFFEN, W. et al. (2015): Planetary boundaries: Guiding human development on a changing planet. Science, 347 (6223), DOI: 10.1123/science. 1259855. 
STEFFEN, W. et al. (2018): Trajectories of the Earth System in the Anthropocene. PNAS 115 (33), 8252 - 8259. DOI: https://doi.org/10.1073/pnas.1810141115 (Navštívené 12. 9. 2018).

SŤAHEL, R. (2017): Environmentálne riziká a existenčné konflikty. In: Suša, O., Hrubec, M. a kol.: Riziková společnost a globální ohrožení. Ke kritické teorii Ulricha Becka. Praha: SLON, $163-178$.

SŤAHEL, R. (2018): Environmentalizmus ako politická filozofia pre 21. storočie. Filozofia, 73 (1), $1-13$.

WORLD COMMISSION ON ENVIRONMENT AND DEVELOPMENT (1987): Our Common Future. Oxford: Oxford University Press.

ZHENHUA, X. - JIAHUA, P. (2018): China's Road of Green Development. Beijing: Foreign Language Press.

Táto štúdia vznikla s podporou grantu VEGA č. 1/0291/18 Historicko-filozofická analýza environmentálneho myslenia, skúmanie jeho vplyvov na etické, právne a politické myslenie a jeho spoločenská odozva.

Richard St'ahel

Filozofický ústav SAV

Klemensova 19

81364 Bratislava 1

Slovenská republika

e-mail: richard.stahel@savba.sk 